\title{
Character-Defining Elements of Shophouses Buildings in Taiping, Perak
}

\author{
Nur Farhana Azmi ${ }^{1 *}$, Yong Adilah Shamsul Harumain ${ }^{2}$, Azlan Shah Ali $^{3}$, Siti Farrah \\ Zaini $^{4}$ and Muhammad Faris Abdullah ${ }^{5}$ \\ ${ }^{1,3,4}$ Centre for Building, Construction and Tropical Architecture (BuCTA), Faculty of Built \\ Environment, University of Malaya, Kuala Lumpur, Malaysia \\ ${ }^{2}$ Centre for Sustainable Urban Planning \& Real Estate (SUPRE), Faculty of Built \\ Environment, University of Malaya, Kuala Lumpur, Malaysia \\ ${ }^{5}$ Department of Urban and Regional Planning, Kulliyyah of Architecture and Environmental \\ Design, International Islamic University Malaysia, Kuala Lumpur, Malaysia
}

*farhanazmi@um.edu.my

The quality of cultural resources in influencing the distinctiveness of a place is rooted in its tangible and intangible features or collectively known as character-defining elements. While it is undeniable that a place is noticeable and regarded as meaningful due to its cultural heritage values, it is important to know where these significances lie or reside in, along with its current importance to the local community. Nevertheless, there is no single definitive list of the elements that is made available to date. Therefore, this research attempts to explore the key features of a place that can contribute to the unique character of a town and substantially drive the subsequent conservation process. A questionnaire survey was conducted in Taiping, a small town in the state of Perak to identify the key elements that define the overall value of a place, particularly shophouses buildings. Tangible and intangible features were identified as the character-defining elements of shophouses that are worthy of being preserved and maintained. The paper concludes to an interesting result where an intangible characterdefining element is the most important feature that characterised the shophouses in the town.

Keywords: Character-defining, identity, liveable, place, shophouse

\section{INTRODUCTION}

Old buildings, particularly shophouses act as an important component that contributes in shaping the identity of a town. Most importantly, these shophouses possess many historically significant features which enables the local authorities and communities who appreciate heritage to protect and preserve the buildings especially from development's pressure. However, it is undeniable that the demands to fulfill the needs of modern lifestyle have caused the town's environment to change dramatically over the years. Several researches conducted on shophouses in Malaysia concluded that the historic atmosphere of shophouses in town in these present days only remained in the memory of older generations due to the aggressive modern development (Wan Ismail \& Shamsuddin, 2005; UMNUS, 2010; Mohd Baroldin \& Mohd Din, 2012).

As the threat of modern development is currently unstoppable, it is crucial to take some potential measures to preserve the priceless historic environment of shophouses and its features as highlighted by Wan Ismail \&
Shamsuddin (2005). The authors further highlighted that the shophouses actually do strengthen the identity not only for the town but also for the country. Place identity, in turn, supports social cohesion and well-being, and subsequently the liveability within an urban environment. As argued by the World Bank (2012), places with distinct identity create liveable places where people choose to live in, work, visit and do business. The cultural heritage assets are a key component in creating liveable towns by providing a unique character and identity for a sense of place (Koh \& Melic, 2017). Cherchi (2015) and Rodriguez Algeciras et al. (2016) further supported that liveable urban environment is made possible by the way historic buildings are maintained and preserved.

Considering the positive influence of cultural heritage on vibrancy and liveability of an environment, this paper attempts to explore the key elements that define the overall value of a place as an initiative to preserve the historic environment of shophouse buildings which are called as character-defining elements. Identifying character-defining 
elements is crucial because the elements will be able to provide the definition of historic character of buildings (Azmi et al., 2015). Furthermore, there is no exact definition on listing the character-defining elements. This paper begins by reviewing the approach and thought on the emergence and importance of character-defining elements in conserving and preserving built heritage. For the purpose of this research, the details on every element are discussed further by using case study of shophouses in Taiping. The key finding of this research would be the identification of tangible and intangible character-defining elements that are considered as significant by the respondents.

\section{CHARACTER-DEFINING ELEMENTS}

There are always different ways of identifying the significant historic and heritage values that lie on a building. For Nelson (1988), every building portrays its own significant character, especially the shape, craftsmanship, materials, decorative details, interior spaces and features, and surrounding environment. A discussion on the quality of design came later which mentioned that the character of building design depends on the architectural approach that compliments the authenticity and integrity of its historical values (Parks Canada, 2011).

Character-defining elements (CDE) are interpreted as the tangible key features that express the heritage values that lie on a building and these include its unique character, sense of place, and time (Jandl, 1988; Federal Heritage Buildings Review Office, 2009; Park Canada, 2011). Identifying the characterdefining elements that make a place significant and the types of significance it conveys is equally important (Azmi et al., 2015). Identifying, preserving, and maintaining these elements seems necessary as the matter of fact that $\mathrm{CDE}$ are taken as the consecutive conservation process and any radical actions that may destroy the elements can be avoided (Jandl, 1988; Kerr, 2007; Federal Heritage Buildings Review Office, 2009).

Neither exhaustive nor prescriptive, the Government of Canada has broadly listed the key features in the Standards and guidelines for the conservation of historic places in Canada as materials, forms, location, spatial configurations, uses, and cultural associations and meanings (Parks Canada, 2011). On the contrary, the United States Department of the Interior National Park Service in America stated that the interior features of a building can be more significant in expressing the history and development of the building. Jandl (1988), however, argued that the interior elements do contribute to the sense of place and time, as similar as the exterior elements do. In combining both exterior and interior elements, buildings and interior spaces, with additional of architectural landscape are connected with personal memories and local heritage that define each building's character. Preservation Brief 17 provides recommendations to identify $\mathrm{CDE}$ for both exterior and interior in a three-step approach. The first step is to understand a building's overall setting and its architectural context. Secondly, assess the materials, craftsmanship, and finishes. The final step is to examine the interior of a building to observe its spaces and details. An additional element of sound was further recommended by Gunderlach (2007) as one of CDE as sound is able to alter and shape the character of a building's space.

In 1988, the understanding of CDE is focused on tangible and intangible key features that convey significant history or heritage values of a building. Parks Canada (2011) then suggested differentiating and categorising $\mathrm{CDE}$ between tangible heritage values including materials used, forms, location, and spatial configuration of a building while intangible elements are comprised of uses, social culture, and associations with town's history as well as the sound as the latest intangible element in the list. According to National Heritage Act 2005 (Act 645), tangible heritage includes the area, monument, and building while intangible includes any form of expressions, language, lingual utterances, sayings, musically produced tones, notes, audible lyrics, songs, folk songs, oral traditions, poetry, music, dances as produced by the performing arts, theatrical plays of audible compositions of sound and music, martial arts that may have existed or exist in relation to the heritage of Malaysia or any part of Malaysia or in relation to the heritage of a Malaysia community (Government of Malaysia, 2012).

\subsection{Tangible Character-Defining Elements}

Every element that contributes to the spatial configuration of a town such as size, shape, construction design, materials, colour and ornaments of buildings conveys to the significant identity and image of a town, therefore, each element is crucial to be preserved and protected (Idid, 1995). 
The identification of tangible CDE can be done in a specific approach. According to Nelson (1988), the visual or tangible element such as a building's shape can be explained by the number of stories in a building; building's roof to be identified by the design and features such as chimney, the design of an opening for the building, such as porches or bay windows and sizes; the building's setting that contributes to their overall character; and other various exterior materials selection used to represent the building character. Once the architectural elements are identified, the buildings materials and surface finishes will be examined before a detailed observation on its interior visual character is carried out (Nelson, 1988).

\subsection{Intangible Elements}

\section{Character-Defining}

As discussed in Section 2, intangible elements of CDE include the use of the building, social culture, associations with town's history, and sound. Azmi et al. (2015) stressed that buildings' use does play a critical role in defining the economic and social values of buildings in a town. On the other hand, the associations of a place with a town's history are a crucial element. This is supported by the Australia ICOMOS (2000) which clearly stated that a place possesses historic values due to the influence by historical figures, events, phases or activities. In addition, a place is able to preserve its own symbolic and significant value as some events and associations that happened were important. Mason (2002) further stated that historical value can be accrued from the age of the place and argued that heritage does not exist without historical values. Architectural design and historical development of a city are a professed stage to identify the historic value of the city (Faizah, 2009). To support the literature, Pearson \& Sullivan (1995) clearly stated that an event or trend from the past of a place does demonstrate the presence of historical values.

Many object-related actions can be identified by sound. It is intangible but seems tangible since it can be felt but not seen or touched (Kahn \& Smith, 2004). When people hear the sound and feel their presence but the vibration will slowly dissipate and modulate before being absorbed or reflected by the actual objects and fill space surrounding them. Gunderlach (2007) stated that soundscape is not only important because of its ability to become an element of place's identity but is also significant in designing and maintaining the landscape.

\section{METHODOLOGY}

This research deployed two stages of methods which begin from the development of concept and understanding to the questionnaire survey. The first stage of this study covers an in-depth understanding of the concept of characterdefining elements of historic buildings. This stage was conducted through a precise and indepth review of relevant literature on character-defining elements, shophouses as well as the background information of research case study, Taiping Town in Perak. Case study approach is necessary for this study in order to illustrate the concept of character-defining elements of a historic place as clearly stated in Section 2. The relevant literature consists of published journals, books and official governments' documents, especially from the Taiping Municipal Council.

The second stage of this study involved a questionnaire survey. Questionnaires were distributed to respondents to achieve the intended research objectives. Buildings users and buildings owners were selected as the respondents for the purpose of this research. In a number of studies related to identity of a place, building users and owners are the most preferred group to be sampled because the elements that conveyed place identity can be identified by asking people who have familiarity with the place and buildings as a result from constant interaction (daily and directly) with the place (Hull et al., 1994; Oktay, 2002; Puren et al., 2008; Baris et al, 2009). Data gathered from questionnaire survey was analysed using the Statistical Package for the Social Science (SPSS) software version 24. Descriptive statistics were used to summarise and describe every variable included in this research. The results were then presented and discussed in Section 5 of the paper.

\section{BACKGROUND OF CASE STUDY}

This research selected the heritage town of Taiping, located in the north state of Perak as shown in Figure 1. Taiping is recognised as one of the heritage towns with special features under the National Physical Plan 2 (NPP-2). The strategy of NPP-2 is concerned with identifying and promoting the special features of heritage towns as the mechanism to increase their economic potentials (Ministry of Housing and Local Government, 2010). In accordance to NPP-2, this research attempts to explore the 
special features of Taiping town as a possible source of the town's identity.

Taiping lies within the district of Larut Matang, with an area 145.85 hectares that encompass the town of Taiping and Taiping Lake Garden. It began to be developed as a town after the tin mining industry and trading took place at the area. 'Taiping' is a Chinese term that means "everlasting peace" and was given to substitute the name of Kelian Pauh after the Larut War ended in 1874.

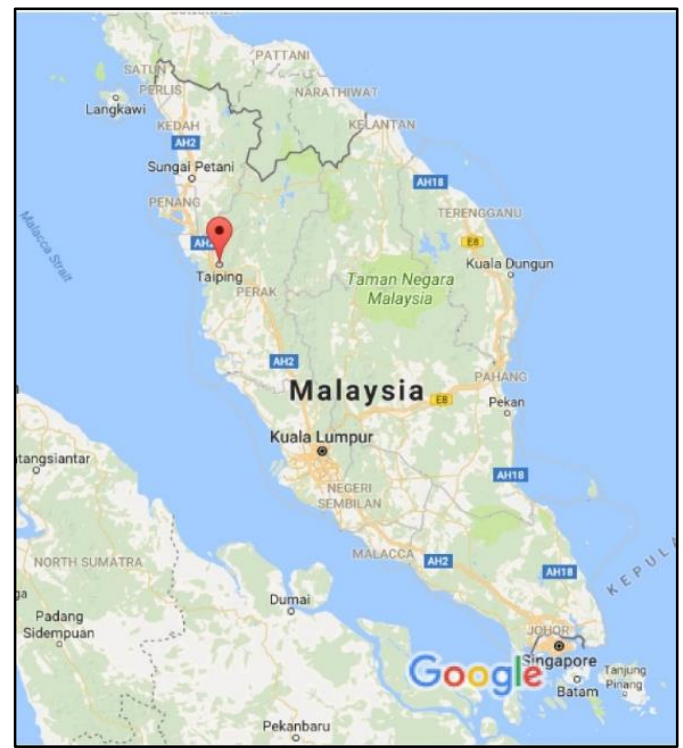

Figure 1: Location of Taiping in peninsular Malaysia

Source: Google Maps (2017)

From the survey, there were several key character-defining elements that made the shophouses in Taiping unique in contrast to other elements within the town area. For example, interesting displays of different façade treatment incorporate different textures, colors and architectural features which essentially confer rich sensory experience to the users as well as strengthening the streetscape image. Variations in these shophouses' façade design interpret different characters of the different era. More features were slowly added to the façade of shophouse from time to time to convey the status of the building's owner (UMNUS, 2010). Although most of the historical shophouses' features in South East Asia countries such as in Malaysia and Singapore are almost similar to each other, there are slightly different features that can characterise shophouses between these countries.

The architectural design, colours, and craftsmanship - According to the morphology of shophouses in the Taiping, the architectural design began from ''Utilitarian', 'Palladian', ''Straits Eclectic',, 'Neo-classical', “'Art Deco"' and finally "'Modern style", during the post-independence of this country. Figure 2 shows the Utilitarian design (1880-1900's) which can be characterised by its plastered masonry wall with no ornamentation. Figure 3 portrays shophouses with the Straits Eclectic design (1901-1910's) which have two or three windows on the upper floor façade. Straits Eclectic design possesses more decorations and ornamentations as compared with Utilitarian shophouses.

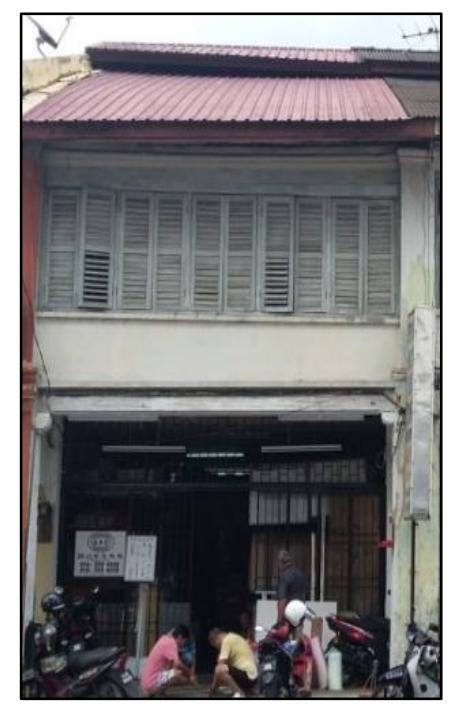

Figure 2: Utilitarian design shophouse

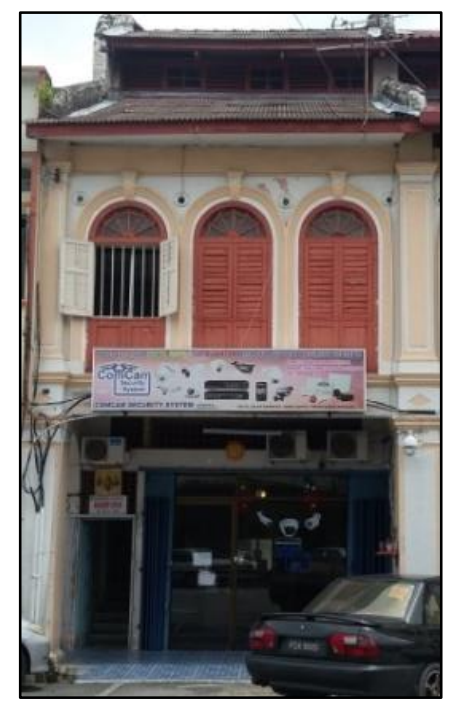

Figure 3: Straits Eclectic design shophouse

Shophouses with Neo-classical design (19101930's) as shown in Figure 4 mainly incorporated straits eclectic design where symmetry is the main principle of ornamentation as well as the addition of plaster renderings at the openings. This style also 
featured tall columns that rise the full height of the building and light colour. The neo-classical design is famously known as 'late straits eclectic style'. Meanwhile, Art Deco (19301940's) in Figure 5 conveys strong geometric design at the façade of shophouse including thin rectangles, circles or continuous horizontal bands on the building's façade.

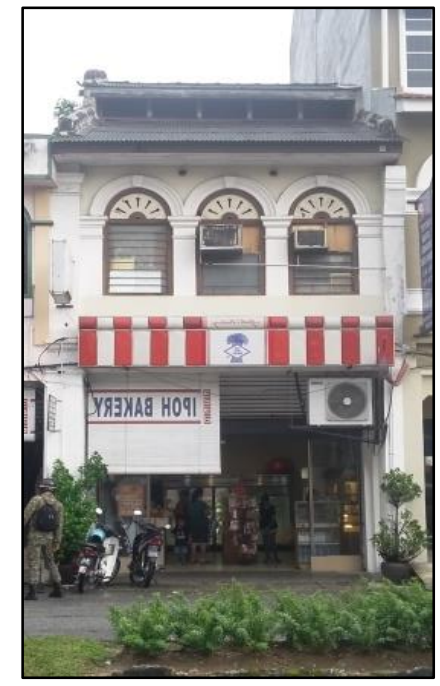

Figure 4: Neo-classical design shophouse

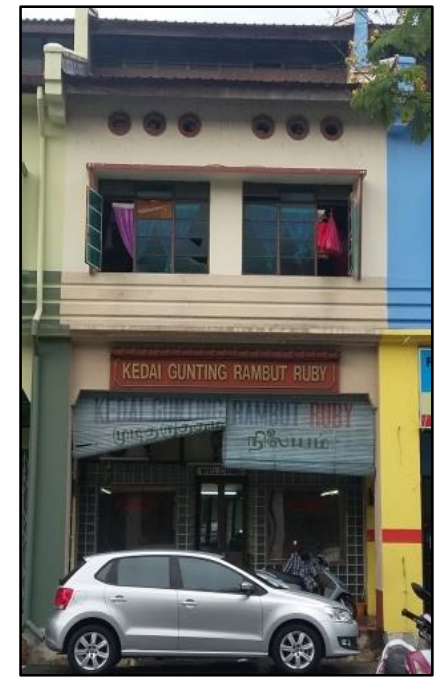

Figure 5: Art Deco design shophouse

Palladian design (1890-1920's) is an unusual style for shophouse in Malaysia as it was mainly portrayed by mansions found in Penang, Kuala Lumpur, and Singapore (Chun et al., 2005). As a matter of fact, according to the Taiping Municipal Council (2017), there are only five significant shophouses with the Palladian design in the Taiping town (Figure 6). Symmetrical design is the main character of Palladian design. Chun et al. (2005) further add that this design used unique shaped balusters and ultimate use of dentils and brackets. Figure 7 shows the shophouses with modern style (1980s) in the Taiping town which frequently uses concrete materials on the façade. Most importantly, $t$ modern style portrays repetitive window openings framed.

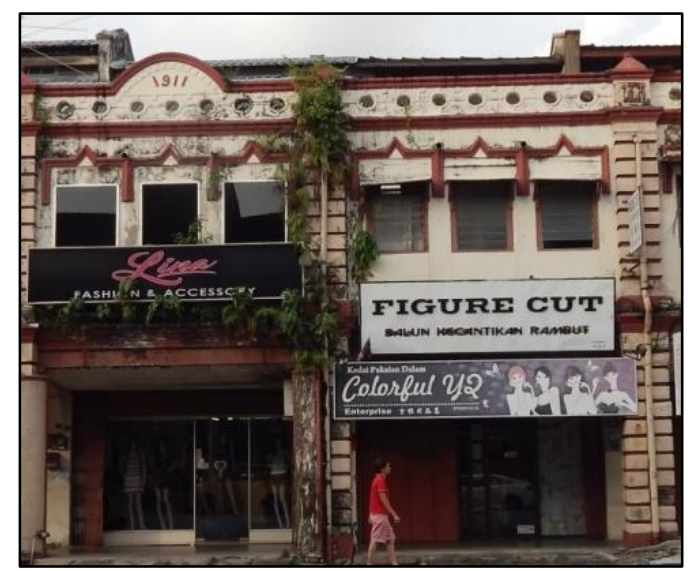

Figure 6: Palladian design shophouse

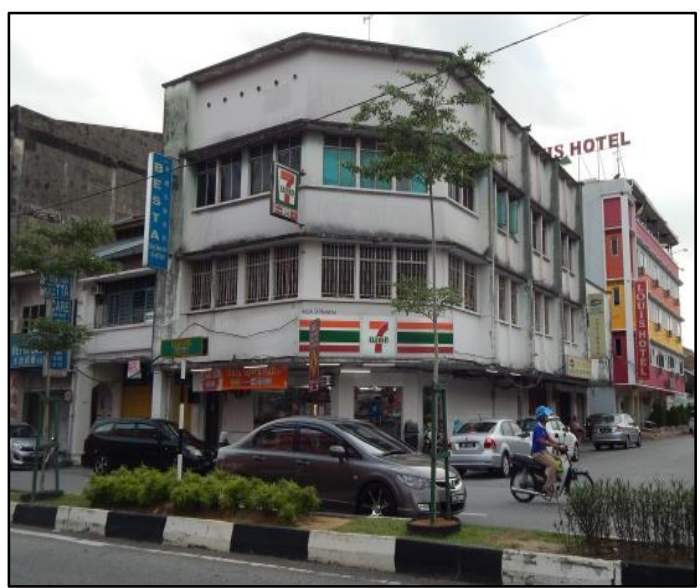

Figure 7: Modern style shophouse

Another dominant feature of shophouses in Taiping lies on its roof design. Taiping is recorded with a significant amount of rainfall throughout the years in Malaysia (ClimateData.Org., 2017). Hence, this significant tropical climate does influence the design of shophouses' roof in the town, particularly the double roofing as shown in Figure 8.

Building uses - Originally, the combination of both trading and residential use constitutes a typical feature of shophouses in the Taiping town. At the earliest era of tin mining in Taiping, tin miners and other workers were working at the ground level and slept at the first level of the same shophouse building. According to Shamsuddin (2011), this has led to a more vibrant and lively atmosphere of the town as well as a safer environment due to the presence of people 
throughout the day and night. Although some of the shophouses still accommodate to both residential and trading use, most of the shophouses are now extensively used for commercial purposes only. This is also supported by the inventory survey conducted by the Taiping Municipal Council (2016). Despite some functional transformation, trading activities conducted in these shophouses increase the sensory experience of the area due to the constant flow of people, and variety of colours and sense of smell that filled the air from the goods and foods sold by the traders.

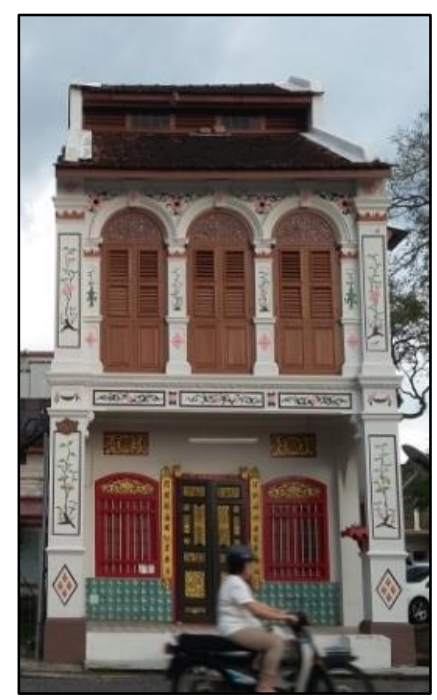

Figure 8: Double roofing of shophouse in Taiping.
Location - Taiping was a former capital city of Perak in the pre-war era. Since the $1840 \mathrm{~s}$, a lot of tin deposits were discovered and as a result, a mining settlement was formed in Taiping town. Due to tin mining activities since the $19^{\text {th }}$ century, British decided to build railways at the town to transport mined tins. This makes Taiping as the first town in Malaya to have a railway station. The strategic location of Taiping has resulted in the town development by British including administration and education centre, and most importantly the emergence of Lake Gardens, a man-made lake which was formed from tin mining activities. Subsequently, the town of Taiping started to be developed with good spatial configurations and circulations (Idid, 1995; UMNUS, 2010).

Spatial configurations - Taiping is impressively documented as a comprehensive and well-planned town as it has a strong grid iron pattern of town which in fact becomes an image and identity of Taiping (Idid, 1995; Taiping Municipal Council, 2016). This means that the organisations of shophouses in this town is in rows of specific widths and are significantly connected to each other. A number of blocks of these rows are separated by streets and a formal grid iron pattern is then formed (Figure 9). Figure 10 illustrates the morphology of town planning in Taiping since the 1850 s until present. This town was wellplanned due to its strategic location as mentioned under the key element of location.

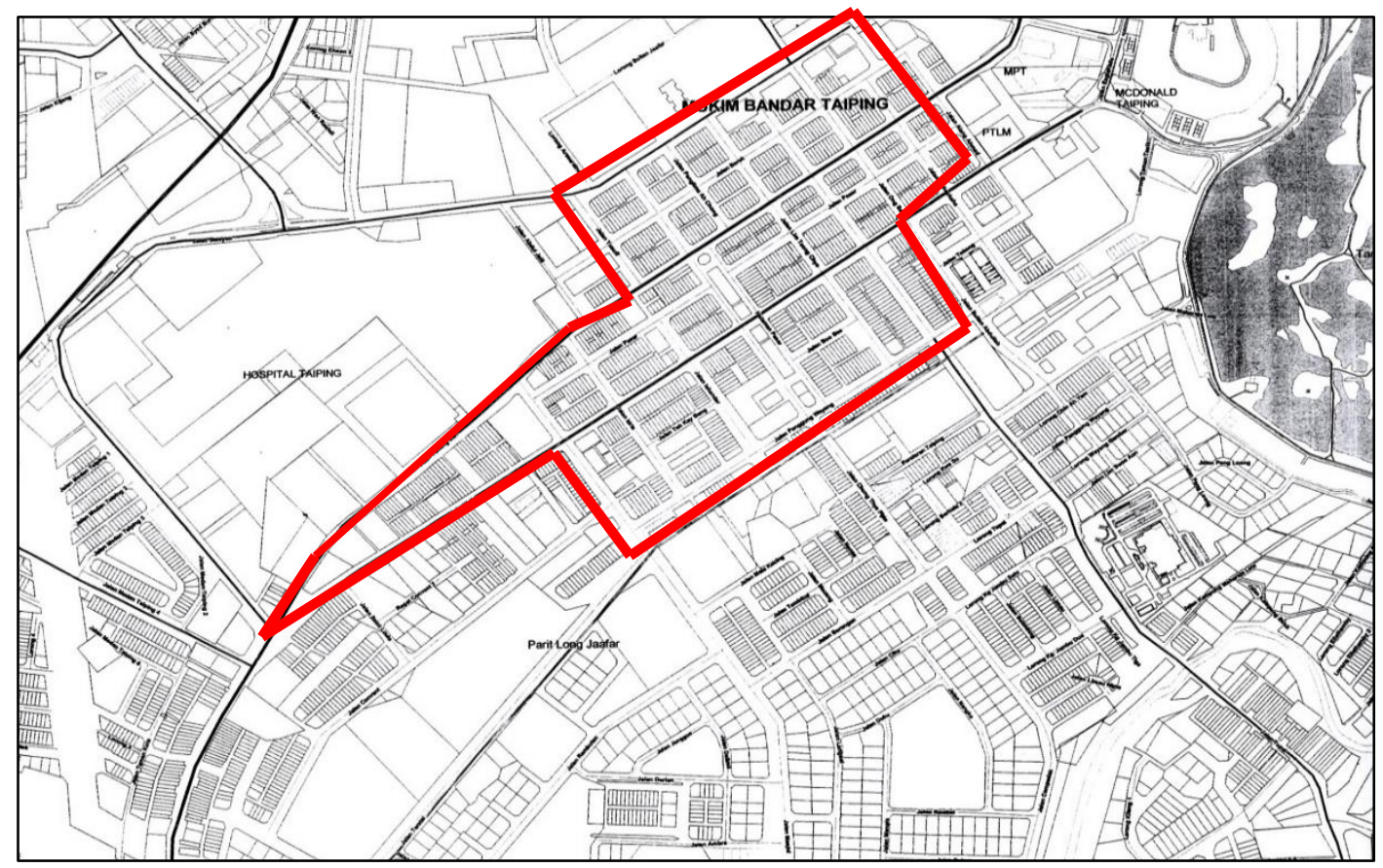

Figure 9: The grid iron pattern of shophouses in the heritage preservation zone of Taiping town Source: Taiping Municipal Council (2017) 

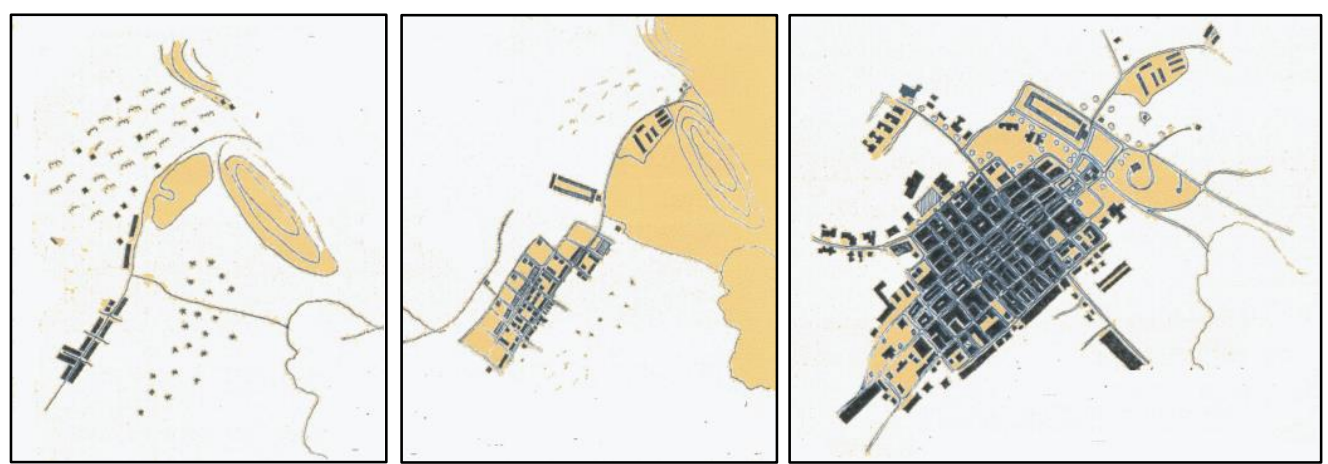

Figure 10: Morphology of Taiping town from 1850s (left), 1881s (center) to 1950s (right)

Source: Taiping Municipal Council (2016)

Size - A majority of the early shophouses in Taiping are two-storey buildings which vary in size. Following the modern rules introduced by the Taiping Municipal Council (2016), these shophouses have evolved to three-storey or more buildings in order to maximise space and cater the problem of land scarcity. The difference in shophouses height and size has encouraged the rich contrast of the area and enhances its recognisability. Figure 11 shows the different size and height of a row of shophouses along Jalan Berek, Taiping.

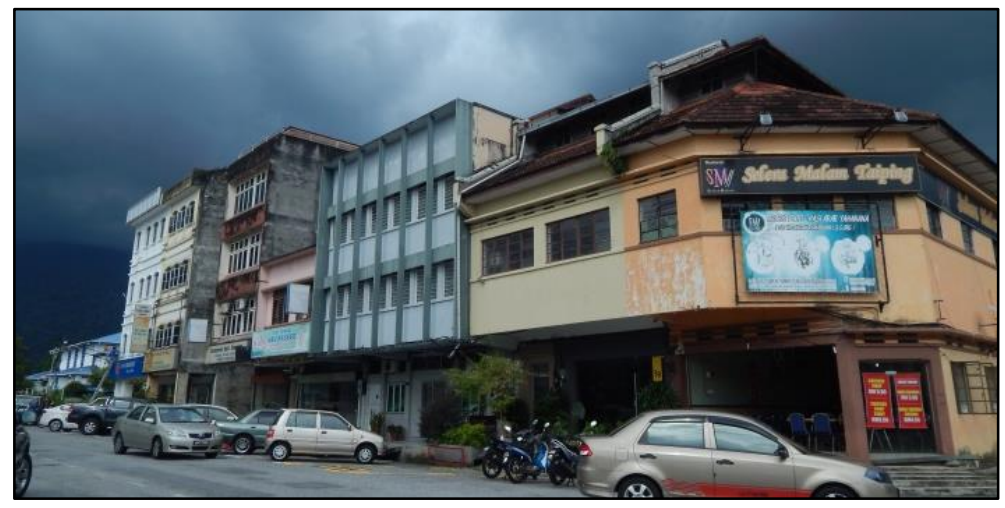

Figure 11: Different size and height of shophouses along Jalan Berek, Taiping

Materials - Building materials such as concrete, wood or steel illustrate the historical timeline or specific period of when the building was constructed. As the shophouses in Taiping are dominated with pre-war buildings, these buildings are constructed from the materials and construction technique during that era, particularly load-bearing wall from bricks, cement, and reinforcement steel (Taiping Municipal Council, 2016) and modern style of shophouses are constructed from reinforced concrete. In addition, terracotta roof tiles are the typical roof materials that characterise the shophouses in Taiping. 5-foot-ways - British was imposing a fivefoot-ways (kaki lima) concept or continuous pedestrian walkway that links the front of the shophouses as a mandatory element for the shophouses (Hashim \& Abd Ghafar, 2005; Idid, 1995). The corridor or five-foot-ways gives the shophouses unique character of its own. As stated in the Special Area Plan of Taiping 2020, the five-foot-ways of shophouses as illustrated in Figure 12 constitutes one of the strong heritage identities of this town that needs to be preserved (Taiping Municipal Council, 2016). 


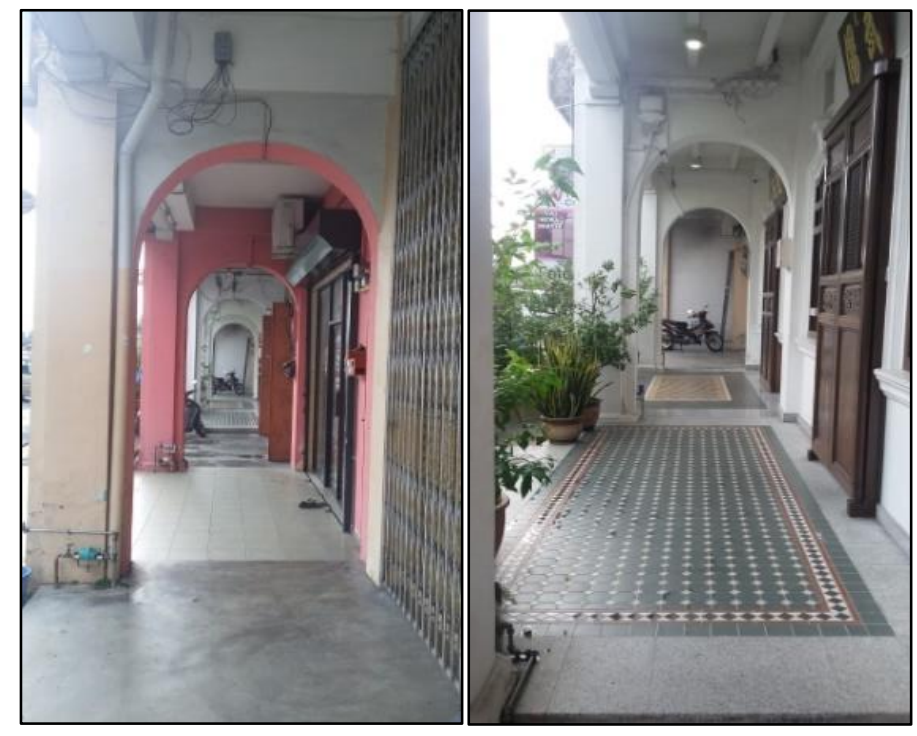

Figure 12: Different features of five-foot-ways in Taiping

Social culture and association with history - Although the shophouses are an attraction, the shophouses also found to be historically significant due to its association with the early development of Taiping town. As argued by Azmi et al. (2015), the associations of a local place and building that has cultural significance with particular events or persons in the past are crucial in imploring the historical significance of place or buildings. Taiping is significantly known for its history as a tin mining town in Perak which was originally discovered by a local, Long Jaafar. Due to this matter, immigrants of Hakka Chinese were brought to work in the mines. The rivalry of two different societies due to disagreements over the mines has required British intervention.

\section{RESULTS AND DISCUSSIONS}

The survey was conducted in April 2017 and a total of 904 shophouses were identified in the preservation zone of heritage Taiping's town. The number of shophouses has increased from 20 years ago where 754 shophouses were documented in 1995. This makes shophouse as a dominant character which covers almost $90 \%$ of the zone. The distribution of these shophouses in the zone is illustrated in Figure 9. Questionnaires were distributed to 101 respondents consisting of buildings owners and buildings users to explore the characterdefining elements of shophouses that can contribute to the unique character of the buildings. As discussed in Section 3, these respondents were employed because of their familiarity to the towns (Hull et al., 1994; Oktay, 2002; Puren et al., 2008; Baris et al., 2009). The respondents were asked to indicate one out of seven elements of identity that attracted to them most.

Table 1 demonstrates that the buildings are the most frequent element noticed by the majority of the respondents, particularly 34 out of 101 respondents which represent 33.7 percent. Natural features come second as selected by 27 respondents (26.7 percent). Street is the least element to be noticed as only one respondent has selected this element. This is an important result because it comes from the perspective of buildings' users that is able to strengthen the fact written by Taiping Municipal Council in Special Area Plan (SAP) of Taiping 2020 which highlighted shophouse as the dominant character of this town. This is also as supported by Wan Ismail \& Shamsuddin (2005) and Azmi et al. (2015) that old buildings act as an important component that contributes in shaping the identity of a town.

Table 1: The most noticeable element in the town

\begin{tabular}{lcc}
\hline First element noticed & $\begin{array}{c}\text { Frequency } \\
(\mathrm{N}=101)\end{array}$ & Percentage \\
\hline Buildings & 34 & 33.7 \\
\hline
\end{tabular}




\begin{tabular}{lcc}
\hline Monuments & 5 & 5.0 \\
Streets & 1 & 1.0 \\
Activities & 13 & 12.9 \\
Natural features & 27 & 26.7 \\
Public open spaces & 18 & 17.8 \\
Smell, sound or sight & 3 & 3.0 \\
\hline Total & 101 & 100.0 \\
\hline
\end{tabular}

The respondents were further required to indicate their level of agreement about the character-defining elements of shophouses in the heritage town of Taiping. CDE are categorised into tangible and intangible elements. The result shown in Table 2 indicates that almost 90 percent of the respondents agreed $(53.5 \%$ strongly agree and $34.7 \%$ agree) that the association with town's history as the most important characterdefining element of shophouses in this town. This is followed by the architectural design of shophouses where 82.1 percent of the respondents agreed that this element is important in influencing the distinctiveness of the buildings. This is a significant finding for this research because this shows that respondents are able to see how this intangible element strongly influences the identity of shophouses in this town. Hence, it should be well-conserved, especially by historic documentation. As supported by Mason (2002), heritage does not exist without historical value.

Table 2: Percentage of tangible and intangible character-defining elements of the town

\begin{tabular}{|c|c|c|c|c|c|}
\hline & & entage & & & \\
\hline $\begin{array}{l}\text { Tangible Character-Defining } \\
\text { Elements }\end{array}$ & $\begin{array}{l}\text { Strongly } \\
\text { disagree }\end{array}$ & Disagree & $\begin{array}{l}\text { Partially } \\
\text { agree }\end{array}$ & Agree & $\begin{array}{c}\text { Strongly } \\
\text { agree }\end{array}$ \\
\hline Architectural Design & 1 & 2 & 14.9 & 46.5 & 35.6 \\
\hline Location & 0 & 3 & 18.8 & 49.5 & 28.7 \\
\hline Arrangement & 0 & 5.9 & 22.8 & 46.5 & 24.8 \\
\hline Size & 1 & 2 & 31.7 & 50.5 & 14.9 \\
\hline Materials & 2 & 7.9 & 31.7 & 47.5 & 10.9 \\
\hline Craftsmanship & 2 & 3 & 26.7 & 48.5 & 19.8 \\
\hline 5-foot-ways & 1 & 13.9 & 42.6 & 30.7 & 11.9 \\
\hline Colour & 1 & 6.9 & 31.7 & 43.6 & 16.8 \\
\hline \multicolumn{6}{|l|}{ Defining Elements } \\
\hline Use & 0 & 5 & 24.8 & 43.6 & 26.7 \\
\hline Smell, sound and sight & 1 & 8.9 & 26.8 & 40.6 & 22.8 \\
\hline Society culture & 2 & 5.9 & 23.8 & 42.6 & 25.7 \\
\hline Association with history & 1 & 1 & 9.9 & 34.7 & 53.5 \\
\hline
\end{tabular}

The result also demonstrates that more than half of the respondents agreed that the tangible character-defining elements reflect the identity of shophouses in Taiping. These elements include location of shophouses which comes as the first element with the highest number of 
agreed respondents (78.2 percent in total), followed by spatial arrangement of shophouses (71.3 percent in total), craftsmanship (68.3 percent in total), size (65.4 percent in total), colour (60.4 percent in total), and materials (58.4 percent in total). These results have placed emphasis that visual or tangible elements contribute to their overall character and the various exterior materials selection used to represent the building character (Nelson, 1988).

However, it is also interesting to learn that according to the data analysis, five-foot-ways demonstrate the least agreement by the respondents (14.9 percent in total) as the character-defining element of shophouses in Taiping's town. This is in opposition to the fact that five-foot-way element represents one of the shophouses identities in Taiping as stated by the Taiping Municipal Council (2016). A plausible explanation is that the local people may have a limited knowledge and awareness on the key feature that contributes to the character of shophouses in Taiping.

\section{CONCLUSION}

This research indicates the key of a place that can contribute to the unique character of a place and the character-defining elements based on a case study of the shophouses in Taiping and from the perspectives of shophouses' users. The findings from the survey have identified that building is the most noticeable element in the town. An association of town with the history is the most significant element that characterises shophouses in Taiping. This is an important finding that needs to be enhanced because it portrays that the building users in Taiping do appreciate and recognises the intangible element of a town's history as the most important element for the town.

\section{ACKNOWLEDGEMENT}

The authors gratefully acknowledge the financial support of the Bantuan Kecil Penyelidikan, grant no. BK021-2016 established at the University of Malaya.

\section{REFERENCES}

Australia ICOMOS (2000). The Australia ICOMOS charter for places of cultural significance: The Burra Charter 1999.

Azmi, N. F., Ahmad, F., \& Ali, A. S. (2015). Heritage place inventory: A tool for establishing the significance of places. Journal of Design and Built Environment, 15(1), 15-23.

Baris, M. E., Uckac, L., \& Uslu, A. (2009). Exploring public perception of urban identity: The case of Ankara, Turkey. African Journal of Agricultural Research, 4(8), 724-735.

Cherchi, P. F. (2015). Adaptive reuse of abandoned monumental buildings as a strategy for urban liveability. Athens Journal of Architecture, 1(4), 253-270.

Chun, H. K., Hasan, A. S., \& Noordin, N. M. (2005). An influence of colonial architecture to building styles and motifs in colonial cities in Malaysia. Paper presented at the $8^{\text {th }}$ International Conference of the Asian Planning Schools Association, Penang, Malaysia, 11-14 September 2005.

Climate-Data.Org. (2017). Climate: Taiping. Retrieved 25 July, 2017, from https://en.climate-data.org/location/25986/

Faizah, A. (2009). Protecting the built heritage of capital cities: Case studies of Perth and Kuala Lumpur. Curtin University of Technology, Perth, Western Australia.

Federal Heritage Buildings Review Office (2009). A guide to working with the Federal Heritage Buildings Review Office. Canada: Parks Canada.

Google Maps. (2017). Taiping Perak. Retrieved 10.10, 2017, from https://www.google.com.my/maps/place/Ta iping,+Perak/@4.1449852,100.6639952,6. 96z/data $=! 4 \mathrm{~m} 5 ! 3 \mathrm{~m} 4 ! 1 \mathrm{~s} 0 \times 31$ caae5495f2bee 9:0x867dd409a89a1da6!8m2!3d4.851932! 4d100.7416339?hl=en

Government of Malaysia (2012). National Heritage Act (Act 645). National Printing Department.

Gunderlach, J. (2007). Sound: Exploring a character-defining feature of historic places. Journal of Sustainable Technology, 38(4), 13-20.

Hashim, H. A., \& Abd Ghafar, N. (2005). Exploring historical shop-house and townhouse vernacular architectural design and elements as a solution for successful passive low energy housing. Beirut, Lebanon: NDU Press.

Hull, R. B., Lam, M., \& Vigo, G. (1994). Place identity: Symbols of self in the urban fabric. Landscape and Urban Planning, 28, 109-120.

Idid, Z. A. (1995). Pemeliharaan warisan rupa bandar. Kuala Lumpur, Malaysia: Badan Warisan Malaysia.

Jackson, J. C. (1973). The structure and functions of small Malaysian towns. 61, 65-80. 
Jandl, H. W. (1988). Preservation briefs. National Park Service.

Kahn, D. \& Smith, M. (2004). Hearing history. Athens, Greece: University of Georgia Press.

Kerr, A. (2007). Considerations for a valuesbased approach to heritage conservation within Canada.

Koh, M., \& Melic, K. (2017). A historic heart: How heritage districts can make cities more liveable. In: Karthigesu, T., \& $\mathrm{Ng}, \mathrm{M}$. (Eds.), Cultural connections (pp.14-24). Singapore: The Culture Academy Singapore.

Mason, R. (2002). Assessing values in conservation planning: Methodological issues and choices. Los Angeles, California: The Getty Conservation Institute.

McCrea, R., \& Walters, P. (2012). Impacts of urban consolidation on urban liveability: Comparing an inner and outer suburb in Brisbane, Australia. Housing, Theory and Society, 29(2), 190-206.

Ministry of Housing and Local Government. (2010). National Physical Plan 2. Kuala Lumpur, Malaysia: Ministry of Housing and Local Government.

Mohd Baroldin, N., \& Mohd Din, S. A. (2012). Documentation and conservation guidelines of Melaka heritage shophouses. Procedia-Social and Behavioral Sciences, 50, 192-203.

Nelson, L. H. (1988). Architectural CharacterIdentifying the Visual Aspects of Historic Buildings as an Aid to Preserving their Character. Retrieved 22.7, 2017, from https://www.nps.gov/tps/how-topreserve/briefs/17-architecturalcharacter.htm\#summary

Oktay, D. (2002). The quest for urban identity in the changing context of the city. Cities, 19(4), 261-271.

Parks Canada (2011). Standards and guidelines for the conservation of historic places in Canada. Canada: Parks Canada.

Pearson, M., \& Sullivan, S. (1995). Looking after heritage places: The basics of heritage planning for managers, landowners and administrators Melbourne University Press.
Puren, K., Drewes, E., \& Roos, V. (2008). A sense of place and spatial planning in the Vredefort Dome, South Africa. South African Geographical Journal, 90(2), 134146.

Rahman, M. M., \& Imon, S. S. (2017). Conservation of historic waterfront to improve the quality of life in old Dhaka. International Journal of Architectural Research, 11(2), 83-100.

Rodriguez Algeciras, J. A., Consuegra, L. G., \& Matzarakis, A. (2016). Spatial-temporal study on the effects of urban street configurations on human thermal comfort in the world heritage city of CamagueyCuba. Building and Environment, 101, 85101.

Shamsuddin, S. (2011). Townscape revisited: Unravelling the character of the historic townscape in Malaysia. Johor Bahru, Malaysia: Universiti Teknologi Malaysia.

Shamsuddin, S., \& Abu Hassan, N. R. (2013). Liveability of Kuala Lumpur city centre from the perspective of urban design quality. In Zubir, S. S., \& Brebbia, C. A. (Eds), Sustainable City VIII (pp. 12611270), United Kingdom: WIT Press.

Taiping Municipal Council (2016). Rancangan Kawasan Khas Taiping 2020. Perak, Malaysia: Majlis Perbandaran Taiping.

UMNUS (2010). Returning Taiping: The town of tin, rain, commerce, leisure and heritage. Kuala Lumpur, Malaysia: CASA of National University of Singapore \& CORE of Faculty of Environment, University of Malaya.

Wan Ismail, W. H., \& Shamsuddin, S. (2005). The old shophouses as part of Malaysian urban heritage: The current dilemma. Paper presented at the $8^{\text {th }}$ International Conference of the Asian Planning Schools Association, Penang, Malaysia, 11-14 September 2005.

World Bank (2012). The economic of uniqueness: Investing in historic city cores and cultural heritage assets for sustainable development. Washington, DC: The World Bank. 